\title{
Sudangrass uses water at rates similar to alfalfa, depending on location
}

\author{
Mark E. Grismer
}

\begin{abstract}
Although sudangrass hay is the second largest forage crop (next to alfalfa), grown south of Sacramento and its planted area has quadrupled in the past decade, little information is available about its water use or relative water value. We would expect the sudangrass yield-water use relationship to be similar to that of alfalfa. Limited data suggest that under moderate soil salinity conditions in the Imperial Valley, sudangrass water-use efficiency (WUE-the ratio of hay yield to water used) approximates the low end of measured alfalfa WUE.

However, when we account for an estimated salinity-induced yield loss of $15 \%$ in the Imperial Valley, sudangrass WUE approximates the high end of measured alfalfa WUE. In order to better characterize the relationship between water use and crop production, as well as develop information about the relative water value associated with sudangrass-hay production, we compared hay yields and prices with estimated crop water use from 1988 to 1999 in Merced and Stanislaus, Riverside and San
\end{abstract} Bernardino, and Imperial counties. Linear regression analysis between yield and crop water use from the five-county dataset resulted in different WUE values depending on whether or not the Imperial Valley data was included. Variability in the crop-yield-towater-use ratio from year to year was greatest in Imperial County and least in Merced and Stanislaus counties, while irrigationwater values (not including production costs) for sudangrass hay were lowest with the greatest variability in the northern counties.

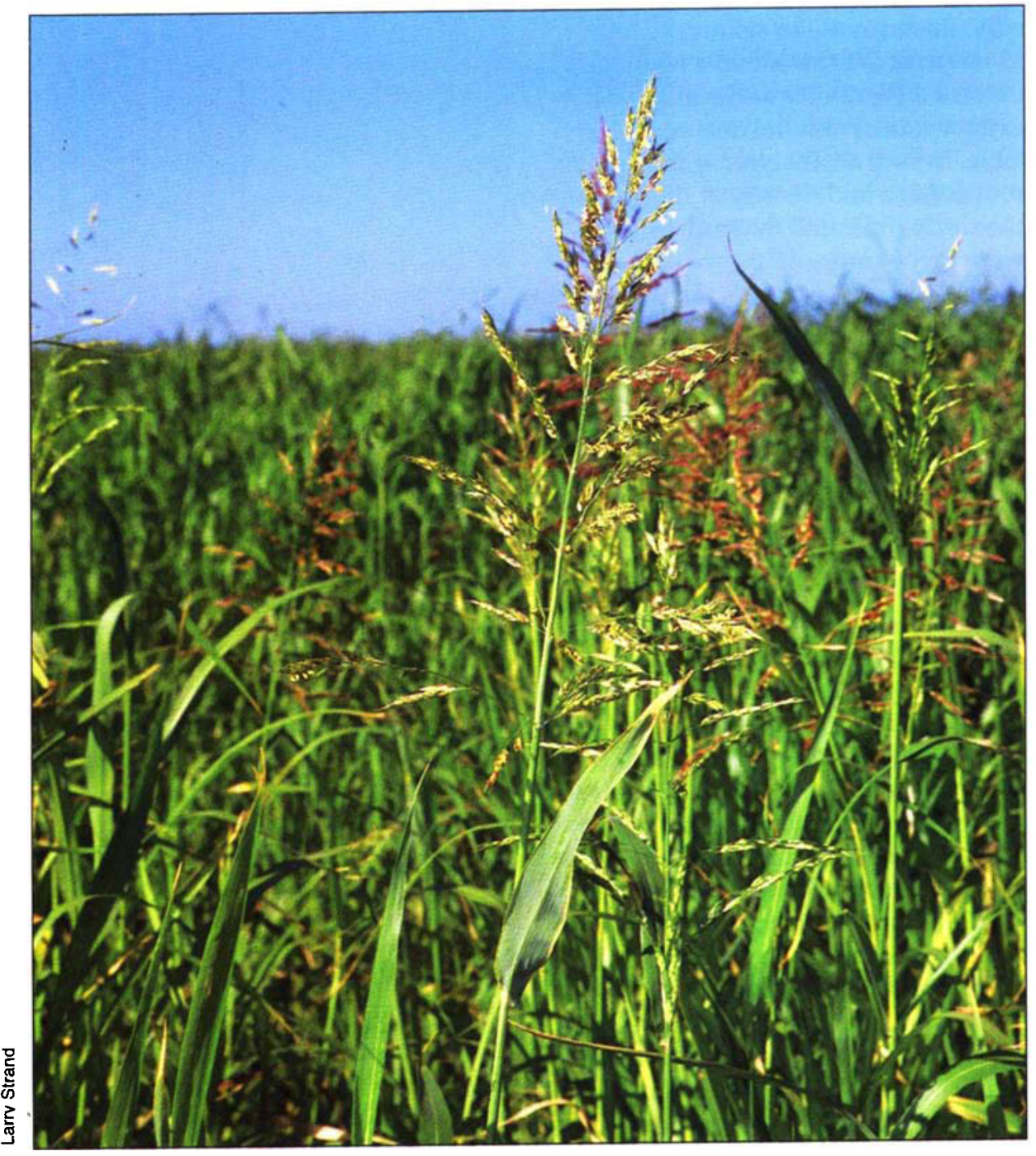

Sudangrass-hay acreage quadrupled from 42,000 acres to nearly 172,000 between 1988 and 1997. However, little is known about its water use.

A $s$ competition for water resources among the municipal, industrial and agricultural sectors of California intensifies, estimations of water value are needed to fairly allocate the limited water supplies available in a region. That is, from a water investment perspective, what is the expected return and variability (the risk) of each unit of water invested in crop production within the region? The production of forage hay (alfalfa and sudangrass) uses a significant amount of water in the state. While the water-use characteristics of alfalfa have been studied intensively, there is very little documentation on the characteristics of sudangrass-hay water use (Grismer 2001). Putnam and Kallenbach (1997) also underscore the importance of evaluating forage-crop water use in the low desert.

Unlike the perennial alfalfa, annual sudangrass is a moderately salt-tolerant 
summer forage crop often grown on somewhat marginal lands in Arizona, and Southern California and San Joaquin Valley. According to county agricultural commissioner reports, the area of sudangrass-hay production in California quadrupled from about 42,000 acres to nearly 172,000 acres between 1988 and 1997. Generally; sudangrass is planted from March through June and harvested as hay between May and October in Southern California. In the desert Riverside, San Bernardino and Imperial counties, hay yields of 5.8 to 7.6 tons per acre result from three to four cuttings; applied water use was approximately 39 inches in the 1990s. In northern San Joaquin Valley (Merced and Stanislaus counties), lower sudangrass-hay yields of 3.9 to 4.9 tons per acre result from two to three cuttings due to relatively lower evapotranspiration.

Agricultural economists have long noted that the greatest economic returns in crop production, or irrigationwater value, may be associated with irrigating less and obtaining somewhat lower than maximum yields (Ayer and Hoyt 1981). This approach at estimating return or value depends on the particular crop/water production function $\left(Y=f\left[\mathrm{ET}_{c}\right]\right)$, which may be difficult to determine.

From a plant physiology perspective, crop yield ( $\mathrm{Y}$ ) should be related to crop water use (ET), though for practical reasons, or simplicity, some have related yield to applied water (AW), or reference evapotranspiration $\left(E_{0}\right)$. Under nonstress conditions, the crop/water production function is linear with a nonzero intercept and a positive slope, meaning that yields generally increase in proportion to the amount of water applied. The slope of this relationship is referred to as crop water-use efficiency (WUE).

For harvestable hay yields, the crop/water production function has a negative yield intercept (meaning that if water drops below a certain point no crop is produced), due to nonharvestable root development. Since the crop/water production function is linear, water-use efficiency is indepen- dent of crop water use and depends primarily on the plant's carbon dioxide $\left(\mathrm{CO}_{2}\right)$ assimilation capacity, or photosynthetic efficiency and plant type (for example, C3, C4 or leguminous). By definition, WUE is constant for each particular plant species. For alfalfa hay, it has been measured in the range of 2.18 to 2.45 tons per acre-foot (16 to $18 \mathrm{~kg} / \mathrm{ha}-\mathrm{mm}$ ) using lysimeters and carbon dioxide assimilation techniques.

Asseng and Hsiao (2000) noted that the water-use efficiency of alfalfa hay is less than that reported for nonlegumes, but similar to that of other legumes (such as soybeans), and suggested that the smaller water-use efficiency may be due to the partial allocation of carbon for nitrogen fixation. When alfalfa yield is related to applied water (rather than crop water use), a nonlinear or curved relationship results. After maximum yield is achieved, it either levels off or decreases with increasing applied water as a result of excess water applications, beyond accumulated crop water use. Furthermore, reduced alfalfa-hay yields at high applied water depths in the Western states are probably the result of heat and salinity-stress losses rather than excess water application (Grismer 2001).

Little, if any, information is available about the crop/water production function ( $\mathrm{Y}=f\left[E \mathrm{~T}_{\mathrm{c}}\right]$ ) for sudangrass hay or its crop coefficient $\left(\mathrm{K}_{\mathrm{c}}=\mathbf{E T} \mathrm{T}_{\mathrm{c}} /\right.$ $\mathrm{ET}_{\mathrm{o}}$ ), though they are expected to be similar to that for alfalfa hay. The crop coefficient describes the ratio of crop water use to evapotranspiration. However, sudangrass is more salt tolerant and capable of substantial osmotic adjustment, meaning that the plant is better able to expel salts through cell membranes (Li et al. 1993); as a nonlegume, it should have a greater water-use efficiency. Bali et al. (2001) and Jensen (1995) measured and estimated crop-yield-to-water-use ratio $\left(\mathrm{Y} / \mathrm{ET}_{\mathrm{c}}\right)$ for sudangrass of 2.12 tons per acre-foot for production in the Imperial Valley from 1995 to 1998 ; the value was less than the expected water-use efficiency for sudangrass. However, we estimated that their ratio may be about $15 \%$ too low due to salinityinduced yield losses (Bali et al. 2001). Jensen (1995) estimated that the seasonal crop coefficient $\left(\mathrm{K}_{c}\right)$ for sudangrass-hay production in the Imperial Valley is 0.87 , a value very similar to the general 0.85 value proposed by Allen et al. (1998); few, if any, measured values exist.

\section{Evaluating return and risk}

In order to provide useful information for decision-making about regional water allocations, we must develop and evaluate long-term (averages and variations) for regional relationships among hay yields, hay prices and crop water use, based on production values that incorporate the actual range of climate, soils and salinity-stress effects on hay yield (Grismer 2001). Hypothetically, a linear crop/water production function $\left(\mathrm{Y}=f\left[\mathrm{ET}_{\mathrm{c}}\right]\right)$ suggests that the irrigation-water value for hay should be greatest in areas where matching rainfall contributes to hay crop water use; however, this matching investment may be countered by a smaller available ET energy (the amount of energy and water available for crop metabolism and growth) in these areas and its greater variability, or investment risk. Therefore, maximum irrigation-water values may in fact occur in regions with a combination of some rainfall and high available ET energy. We completed this analysis for alfalfa hay (Grismer 2001), but a similar study is lacking for

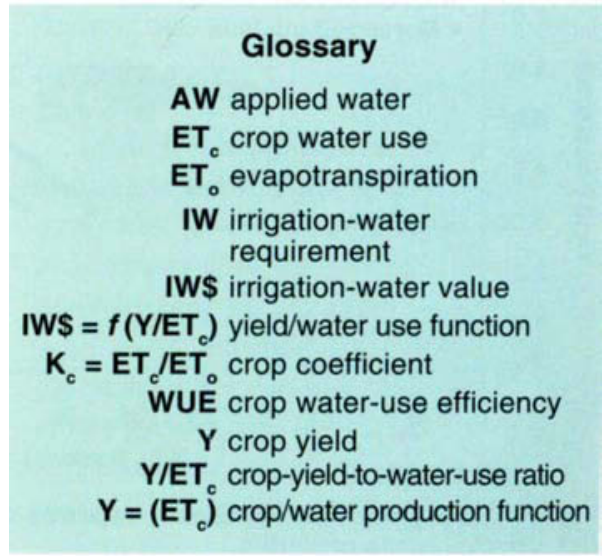


the second largest forage crop, sudangrass hay. This study attempts to address the sudangrass-hay water investment question in California by:

Estimating the water-use efficiency (WUE) and crop-yield-to-water-use values $\left(\mathrm{Y} / E T_{c}\right)$ for sudangrass hay, and their variability.

- Estimating the irrigation-water value (benefit) associated with sudangrass-hay production and comparing these values with that for alfalfa-hay production.

Moreover, mean crop-yield-to-wateruse values $\left(\mathrm{Y} / \mathrm{ET}_{c}\right)$, with their associated variance, may serve as target, or reference, values to which we may compare those resulting from alternative irrigation-water strategies within a desired confidence level (variance).

\section{Comparing water use}

We collected data from five counties producing sudangrass hay between 1988 and 1999, including hay production and prices, reference evapotranspiration and rainfall records. Sudangrass-hay production was obtained from annual county agricultural commissioner reports and reflects yields at $10 \%$ to $12 \%$ of moisture content. We calculated seasonal crop water use as the product of the seasonal crop coefficient of 0.85 (Allen et al. 1998), which we considered to be applicable to all counties, and we averaged the growing-season evapotranspiration from all California Irri- gation Management and Information System (CIMIS) stations located in the county (or counties).

The growing seasons for sudangrass hay are about the same duration throughout California, although the planting dates may vary by as much as 1 month, depending on cropping rotations and spring season weather. San Joaquin Valley growers may plant in April, while Imperial Valley growers often plant in March; nonetheless, we assumed that the growing-season lengths were the same. We took the seasonal minimum irrigation-water requirement (IW), as seasonal crop water use minus average measured seasonal rainfall (though small), and assumed all rainfall to be effective in replenishing soil moisture.

While this estimate of irrigation-water requirement is probably fairly accurate for the desert and near-desert counties, it probably overestimates irrigation-water requirements in Merced/Stanislaus counties because of available soil moisture from winter rains. The irrigation-water requirement was not adjusted for application efficiency or leaching fractions, so we could readily compare between counties as well as develop a common basis for determining irrigation-water value. Irrigation-water value (IW $\$$, in dollars per acre-foot), or benefit (not including production costs), is the product of marketyear average hay prices (dollars per ton) and the crop-yield-to-irrigation-water ratio (Y/IW, in tons per acre-foot).

\section{Counties differ}

We considered estimates of yieldto-irrigation-water ratio $(\mathrm{Y} / \mathrm{IW})$ and irrigation-water value (IW\$) first, followed by development of the crop/ water production function, and we estimated water use, irrigation requirement and irrigation-water values, and their variability, from 1988 to 1999 for the five counties (table 1). The average crop-yield-to-water-use ratio for sudangrass-hay production of 1.89 tons per acre-foot in Riverside/San Bernardino counties was greater than that for Imperial County (1.70 tons per acre-foot), despite slightly smaller seasonal crop water use (39.5 inches versus 41.5 inches).

Both desert areas had similar, relatively high, crop-yield-to-water-use ratio variability (Coefficient of Variation $=$ standard deviation $/$ mean; $\mathrm{CoV}=$ $18.3 \%$ to $18.5 \%$ ). In contrast, the average sudangrass crop-yield-to-wateruse ratio for Merced/Stanislaus counties was the smallest (1.30 tons per acre-foot) with the least variability $(\mathrm{CoV}=13.6 \%)$, due to considerably smaller average seasonal crop water use (32.5 inches).

By way of comparison to alfalfa-hay production, the average sudangrass crop-yield-to-water-use ratio was considerably less than that for alfalfa-hay production in Merced/Stanislaus counties (1.86 tons per acre-foot), while it was greater for Imperial and Riverside/San Bernardino counties during the same period (1.56 and 1.52 tons per acre-foot, respectively). Al-

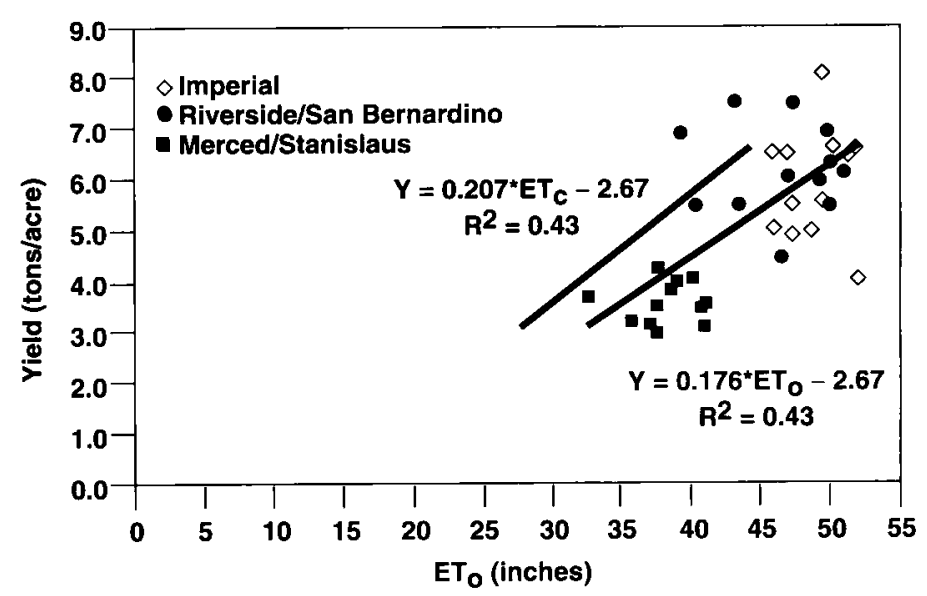

Fig. 1. Sudangrass-hay yield as it depends on evapotranspiration (ET) in California counties.

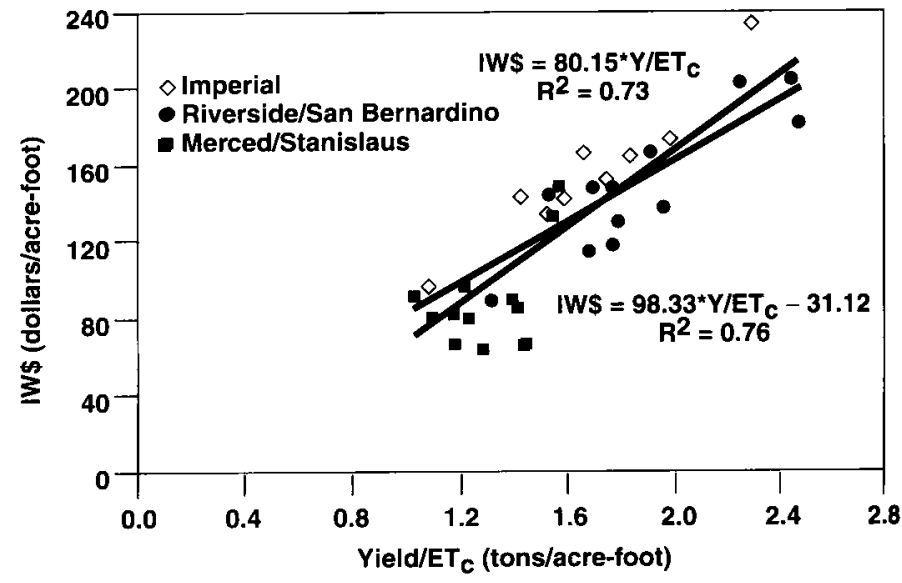

Fig. 2. Irrigation water value (IWS) for sudangrass hay as it depends on crop-yield-to-water-use (Y/ET $T_{c}$ ) in California counties. 
though irrigation-water value as hay fluctuated considerably from year to year (about $\$ 86$ and $\$ 234$ per acrefoot), average sudangrass-hay irrigation-water value was greatest for Imperial County ( $\$ 150$ per acre-foot) due to consistently better hay prices, as compared with that for Riverside/San Bernardino and Merced/Stanislaus counties (about $\$ 148$ and $\$ 89$ per acrefoot, respectively).

However, due to potential overestimation of the irrigation-water requirement for Merced/Stanislaus counties, as noted above, the computed irrigation-water values may be artificially low. Corresponding average irrigation-water values for alfalfahay production during the same period were reversed; that is, they were greatest for Merced/Stanislaus counties ( $\$ 238$ per acre-foot) followed by Riverside/San Bernardino (\$175 per acre-foot) and Imperial ( $\$ 150$ per acrefoot). Interestingly, average irrigation-water values for sudangrassand alfalfa-hay production in the Imperial Valley were equivalent.

Significant linear regression relationships were obtained between sudangrass-hay yield, evapotranspiration and crop water use, and the irrigation-water value and crop-yieldto-water-use ratio for all five counties, as well as the four counties excluding Imperial County (table 2). As noted in the crop/water production function for alfalfa hay, sudangrass-hay yields increase with water use to a maximum value and then level off for data from the low desert, or Imperial Valley (fig. 1) (Grismer 2001).

Based on the smaller average cropyield-to-water-use ratio - relative to crop water use - obtained for Imperial County, this data set was initially segregated from the data set as a whole. The slopes (WUEs) and intercepts of the crop/water production function represent the data set as a whole and - without the Imperial County data - did not appear to differ significantly. Excluding the Imperial County data, the slope of the crop/water production function (WUE), and intercept for sudangrasshay production were slightly greater (2.82 tons per acre-foot and -3.57 tons

TABLE 1. Sudangrass-hay yields ( $Y$ ), estimated evapotranspiration (ET $)$, yield/water-use ratios (Y/ET $)$ and water values (IW, IWS) for producing counties in California

\begin{tabular}{|c|c|c|c|c|c|c|c|c|c|c|c|c|c|}
\hline \multirow[b]{2}{*}{ Year } & \multicolumn{5}{|c|}{ Imperial } & \multicolumn{4}{|c|}{ Riverside/San Bernardino } & \multicolumn{4}{|c|}{ Merced/Stanislaus } \\
\hline & ET。 & IW & Yield & $\mathrm{Y} / \mathrm{ET}_{\mathrm{c}}$ & IWS & ET。 & IW Yield & Y/ET。 & IWS & ET。 & IW & Yield & Y/ET \\
\hline & in. & n. & t/ac & t/ac & $-f t$ & in. & in. $t / a c$ & $t / a c-f t$ & \$/ac-ft & in. & in. & tac & /ac-ft \$/ac-ft \\
\hline 1988 & 49.5 & 42.0 & 5.54 & 1.58 & 142.58 & 43.4 & 36.75 .47 & 1.78 & 148.58 & 37.8 & 32.0 & 3.47 & $1.30 \quad 61.74$ \\
\hline 1989 & 52.1 & 44.3 & 4.00 & 1.08 & 92.22 & 49.4 & 41.95 .88 & 1.68 & 114.43 & 40.9 & 34.8 & 3.52 & 1.2180 .27 \\
\hline 1990 & 49.3 & 41.9 & 8.00 & 2.29 & 234.03 & 49.9 & 42.46 .93 & 1.96 & 135.19 & 37.1 & 31.4 & 3.05 & 1.1681 .10 \\
\hline 1991 & 45.9 & 39.0 & 5.00 & 1.54 & 133.93 & 40.3 & 33.95 .50 & 1.93 & 165.28 & 40.8 & 34.6 & 3.40 & 1.1864 .86 \\
\hline 1992 & 46.8 & 39.8 & 6.50 & 1.96 & 135.32 & 50.1 & 42.56 .29 & 1.77 & 117.25 & 38.9 & 33.0 & 4.00 & 1.4565 .50 \\
\hline 1993 & 51.7 & 44.0 & 6.54 & 1.78 & 148.08 & 47.2 & 39.97 .49 & 2.24 & 202.62 & 39.9 & 33.9 & 4.02 & 1.4285 .36 \\
\hline 1994 & 50.3 & 42.7 & 6.59 & 1.85 & 163.20 & 50.9 & 43.36 .10 & 1.69 & 147.08 & 37.8 & 32.0 & 4.15 & 1.55132 .22 \\
\hline 1995 & 45.9 & 38.8 & 6.50 & 2.00 & 170.81 & 43.2 & 36.47 .47 & 2.44 & 203.70 & 35.8 & 30.4 & 3.11 & 1.2394 .74 \\
\hline 1996 & 51.2 & 43.5 & 6.36 & 1.75 & 150.98 & 39.3 & 33.16 .88 & 2.47 & 181.02 & 37.4 & 31.7 & 2.91 & 1.1078 .31 \\
\hline 1997 & 47.1 & 40.0 & 5.56 & 1.66 & 165.16 & 47.3 & 40.15 .99 & 1.79 & 129.76 & 41.0 & 34.8 & 3.01 & 1.0488 .18 \\
\hline 1998 & 48.7 & 41.4 & 4.94 & 1.43 & 142.41 & 49.9 & 42.45 .48 & 1.55 & 144.58 & 32.7 & 27.7 & 3.67 & 1.58147 .39 \\
\hline 1999 & 47.3 & 40.1 & 4.87 & 1.45 & 117.68 & $46.5^{*}$ & $393.4^{*} 4.40$ & 1.34 & 90.27 & 38.6 & 32.8 & 3.83 & 1.4088 .61 \\
\hline Mean & 48.8 & 41.4 & 5.86 & 1.70 & 149.70 & 46.4 & 68.86 .16 & 1.89 & 148.31 & 38.2 & 32.4 & 3.51 & 1.3089 .02 \\
\hline $\operatorname{CoV}(\%) \dagger$ & $t 4.62$ & 4.53 & 18.4 & 18.5 & 22.8 & 8.59 & 8.9514 .9 & 18.3 & 23.5 & 6.27 & 6.38 & 12.2 & $13.6 \quad 29.2$ \\
\hline
\end{tabular}

"No evapotranspiration (ET) and rain data were available so the average $\mathrm{ET}_{\mathrm{c}}$ and IW values of the past decade are used.

†Coefficient of Variation $=$ standard deviation $/$ mean

TABLE 2. Linear regression parameters for relationships between sudangrass-hay yields and crop water use (ET $)$, as well as irrigation-water values (IW\$) and crop-yield-to-water-use ratios (Y/ET) in California (1988-1999)

\begin{tabular}{|c|c|c|c|c|c|c|}
\hline \multirow[b]{2}{*}{ Counties } & \multicolumn{3}{|c|}{ Yield $=$ WUE $\left(E T_{c}\right)+b$} & \multicolumn{3}{|c|}{$I W S=c\left(Y / E T_{c}\right)+d$} \\
\hline & WUE* & bt & $\mathbf{R}^{2}$ & c & d & $\mathbf{R}^{2}$ \\
\hline & $t / a c-f t$ & t/ac & & $\$ / t$ & $\$ / a c-f t$ & \\
\hline Five counties $\ddagger$ & 2.48 & -2.67 & 0.43 & 98.33 & -31.12 & 0.76 \\
\hline Without Imperial Co. & 2.81 & -3.60 & 0.49 & 94.93 & -32.60 & 0.80 \\
\hline
\end{tabular}

"WUE: crop water-use efficiency.

tb, $c$ and $d$ are the constants of linear regression.

$\ddagger$ Merced/Stanislaus, Riverside/San Bernardino, and Imperial.

per acre; $R^{2}=0.49$ ), as expected, than the water-use efficiency for alfalfa-hay production we reported in Central Valley (2.54 tons per acre-foot and -2.68 tons per acre, respectively; $R^{2}=0.73$ ) (Grismer 2001). The negative yield intercepts are roughly equivalent to a single hay cutting and represent the vegetative production that is nonharvestable or not harvested.

Irrigation-water value as hay (IW\$) is expected to increase with increasing crop-yield-to-water-use ratio $\left(\mathrm{Y} / \mathrm{ET}_{\mathrm{c}}\right)$ as a result of greater yields per increment of water use (fig. 2). For sudangrass-hay production, the slopes and intercepts of the IW\$ $=f(\mathrm{Y} / \mathrm{ET})$ also depended on whether the Imperial County data were included as a result of differing hay prices between counties rather than differing crop/water production function relationships. The meaning of the IWS $=f\left(\mathrm{Y} / \mathrm{ET}_{\mathrm{c}}\right)$ negative intercept is not clear, since conceptually this value should be zero (no water value when $\mathrm{Y} / \mathrm{ET}_{\mathrm{c}}=0$; no yield should mean that no crop is produced). In both cases, the $\mathrm{IW} \$=f\left(\mathrm{Y} / \mathrm{ET}_{\mathrm{c}}\right)$ slope for sudangrass was less than that for alfalfa-hay production (about $\$ 96$ versus $\$ 120$ per ton). That is, alfalfa has a slightly greater value per unit water use than sudangrass.

\section{A viable crop}

Little information describing the sudangrass water use in the field is available. Based on an analysis of available hay yields, prices and estimated water use for five counties in Southern California and northern San Joaquin Valley, we developed a crop/ water production function relationship and used it to evaluate irrigation-water value. The irrigation-water value for sudangrass hay is similar to that for 


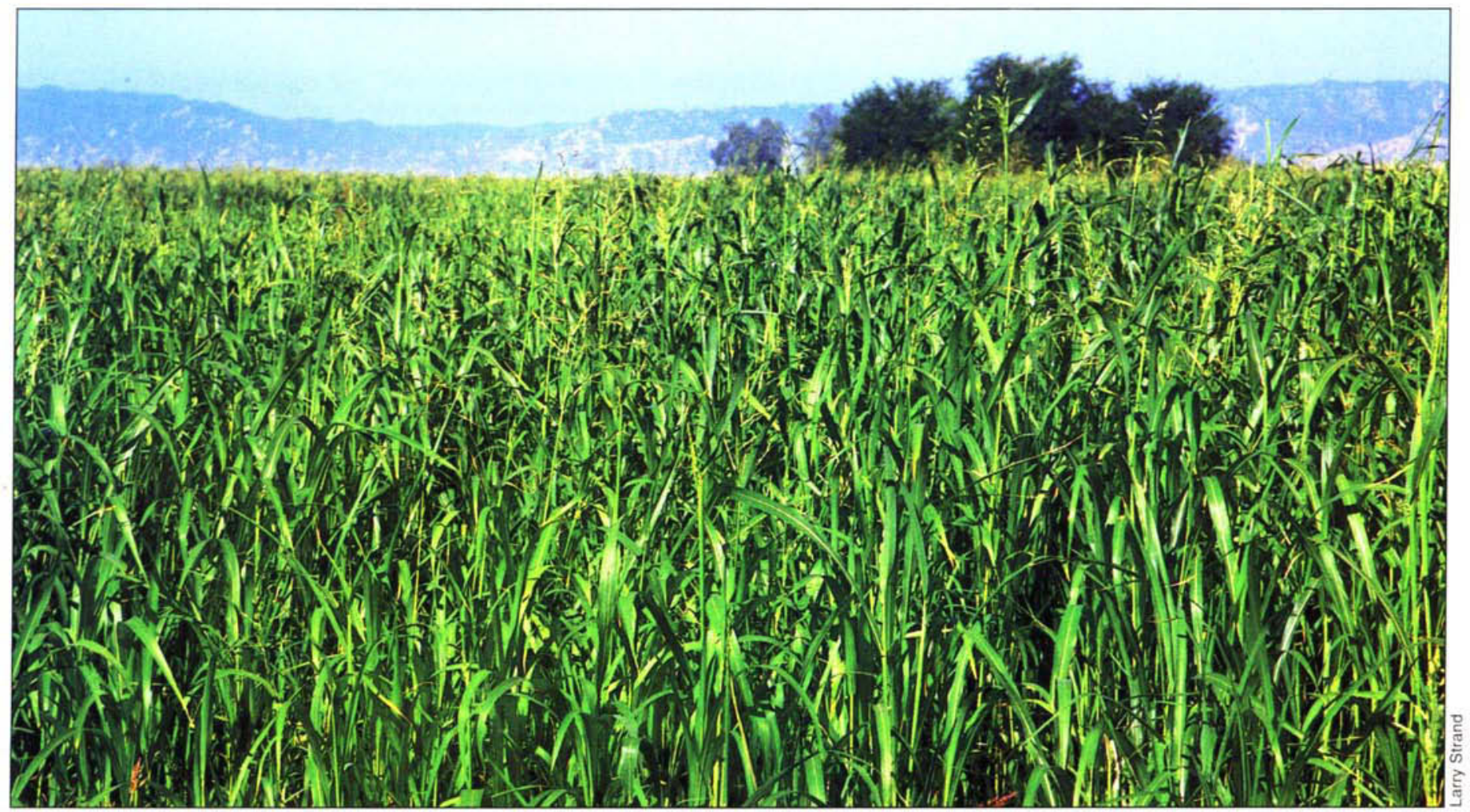

alfalfa hay on average in Imperial County, less for Riverside/San Bernardino counties and lower still for San Joaquin Valley counties.

In all counties, the estimated water value as sudangrass or alfalfa hay is still considerably less than that paid by municipalities (Grismer 2001). However, the salt-tolerance capability of sudangrass suggests that it will probably remain a viable crop for production on marginal or moderately saline lands, because it grows where other crops may not be viable or economically productive.

M.E. Grismer is Professor of Hydrology, and Biological and Agricultural Engineering, UC Davis.

The irrigation-water value for sudangrass hay was similar to that for alfalfa hay in Imperial County, and less so for other counties studied. Because of its salt-tolerance capability, sudangrass should remain a viable crop on marginal or saline land.

\section{References}

Allen RG, Periera LS, Raes D, Smith M 1998. Crop Evapotranspiration - Guidelines for Computing Crop Water Requirements. Irrigation and Drainage Paper 56. Rome: FAO/ UN.

Asseng S, Hsiao TC. 2000. Canopy $\mathrm{CO}_{2}$ assimilation, energy balance and water-use efficiency of an alfalfa crop before and after cutting. Field Crops Res 67:191-206.

Ayer HW, Hoyt PG. 1981. Crop-water production functions: Economic implications for Arizona. Tech Bull 242, Arizona Ag Exp Station and USDA-ERS.

Bali KM, Grismer ME, Tod IC. 2001. Reduced-runoff irrigation of sudangrass hay; Imperial Valley, CA. ASCE J Irrig Drain Eng
127(3):123-30.

Grismer ME. 2001. Alfalfa-hay yield, water use and water value in the Western states. ASCE J Irrig \& Drain Engrg 127(3):131-9.

Jensen ME. 1995. Water-use assessment of the Imperial Irrigation District. Internal report to IID (as reported in Putnam and Kallenbach 1997).

Li X, Feng Y, Boersma L. 1993. Comparison of osmotic adjustment responses to water and temperature stresses in spring wheat and sudangrass. Annal Botany 71(4):303-10.

Putnam D, Kallenbach R. 1997. Growers face critical juncture in desert forage production. Cal Ag 51(3):12-6.

\section{CALIFORNIA AGRICULTURE ASSOCIATE EDITORS}

$\begin{array}{ll}\text { Animal, Avian, Aquaculture } & \text { Food \& Nutrition } \\ \text { \& Veterinary Sciences } & \text { Amy Block Joy } \\ \text { Jim Cullor } & \text { Sheri Zidenberg-Cherr } \\ \text { Christopher M. Dewees } & \text { Human \& Community } \\ \text { Kathryn Radke } & \text { Development } \\ \text { Barbara A. Reed } & \text { Linda M. Manton } \\ \text { Economics \& Public Policy } & \text { Alvin Sokolow } \\ \text { Richard A. Howitt } & \text { Land, Air } \\ \text { Richard J. Sexton } & \text { \& Water Sciences } \\ & \text { Mark Grismer } \\ & \text { John Letey }\end{array}$

Natural Resources Daniel W. Anderson Lynn Huntsinger Richard B. Standiford

Pest Management Donald L. Dahlsten Timothy D. Paine Michael K. Rust Robert Washino

Plant Sciences Jodie S. Holt Lee F. Jackson http://danr.ucop.edu/calag/ CALAG@ucop.edu Phone: (510) 987-0044 FAX: (510) 465-2659 